\title{
Emerging roles of chemokines in prostate cancer
}

\author{
David Vindrieux ${ }^{1,2}$, Pauline Escobar ${ }^{1,2}$ and Gwendal Lazennec ${ }^{1,2}$
}

\author{
${ }^{1}$ INSERM, U844, Site Saint Eloi, Bâtiment INM, 80 rue Augustin Fliche, Montpellier F-34091, France \\ ${ }^{2}$ University of Montpellier I, Montpellier F-34090, France \\ (Correspondence should be addressed to G Lazennec, INSERM, U844, Site Saint Eloi, 80 rue Augustin Fliche, \\ 34295 Montpellier, France; Email: gwendal.lazennec@inserm.fr)
}

\begin{abstract}
Prostate cancer $(\mathrm{PCa})$ represents the second leading cause of death among all cancer types in men in Europe and North America. Among the factors suspected to control PCa, incidence and progression, chemokines, and their receptors are now intensively studied. Chemokines are produced by tumor cells and also by the stromal microenvironment, both in the primary tumor site and in distant metastatic locations. The wide and differential distribution of chemokines and their receptors account for the pleiotropic actions of chemokines in $\mathrm{PCa}$, including the modulation of growth, angiogenesis, invasion, metastasis, and hormone escape. This review will focus on the roles and the mechanisms of action and regulation of chemokines in the different steps of PCa development and will discuss the novel strategies that are currently envisioned to target chemokines in PCa.
\end{abstract}

Endocrine-Related Cancer (2009) 16 663-673

\section{Introduction}

\section{Prostate cancer and chemokines}

Prostate cancer (PCa) is the most commonly diagnosed cancer in males and the second leading cause of death from cancer in men. Its incidence has increased dramatically since the advent of prostate-specific antigen (PSA) screening in the early 1990s. One in six men in the US will be diagnosed with PCa in his lifetime (Jemal et al. 2006). Most PCas, as well as normal prostate tissue, are dependent on the presence of androgens for growth and survival. Localized PCa can be effectively treated with radical prostatectomy or radiation therapy. For more advanced cancers, androgen ablation therapy to block the function of the androgen receptor (AR), has shown beneficial effects only for hormone-responsive early-stage disease (Javidan et al. 2005). Cancer cells that become hormone-independent also become highly invasive, and they reach the clinical stage associated with an increased incidence of skeletal metastases as the disease progresses (Bostwick et al. 2004, Logothetis \& Lin 2005, Taplin 2007, Devlin \& Mudryj 2009). PCa shares a number of features with benign prostatic hyperplasia (BPH) and the putative precursor of cancer, prostatic intraepithelial neoplasia. All three stages of prostate disease increase in prevalence with age and require androgens for growth and development.

So far, the factors responsible for $\mathrm{PCa}$ progression remain elusive. Among the mediators of carcinogenesis, the significance of chemokines in PCa progression has increased. In multicellular organisms, the interactions between individual cells are essential to ensure their correct functions in an appropriate spatial and temporal manner. In particular, cell homing requires a fine tune in embryonic development, inflammation, or immunity. Such events appear to be deregulated in the neoplastic process.

Chemokines are members of a superfamily of chemotactic cytokines (Ali \& Lazennec 2007; Table 1), initially characterized because of their association with inflammatory responses, and by stimulation of leukocyte chemotaxis during inflammation (Thelen 2001, Dowsland et al. 2003). Chemokines constitute a large family (45 human members) of low molecular weight proteins and are mostly secretory in nature (Table 1). The chemokine family can be subdivided in four groups, based on a conserved 
Table 1 The superfamily of chemokines

\begin{tabular}{|c|c|c|}
\hline $\begin{array}{l}\text { New } \\
\text { nomenclature }\end{array}$ & Ligand & Receptor(s) \\
\hline \multicolumn{3}{|l|}{ CXC chemokines } \\
\hline CXCL1 & GRO $\alpha / M G S A \alpha$ & CXCR2, CXCR1 \\
\hline CXCL2 & GRO $\beta / M G S A \beta$ & CXCR2 \\
\hline CXCL3 & $\mathrm{GRO}_{\gamma}$ & CXCR2 \\
\hline CXCL4 & PF4 & CXCR3B \\
\hline \multicolumn{3}{|l|}{ CXCL4V1 } \\
\hline CXCL5 & ENA-78 & CXCR2 \\
\hline CXCL6 & GCP-2 & CXCR1, CXCR2 \\
\hline CXCL7 & NAP-2 & CXCR2 \\
\hline CXCL8 & IL-8 & CXCR1, CXCR2 \\
\hline CXCL9 & MIG & CXCR3, CXCR3B \\
\hline CXCL10 & IP-10 & CXCR3, CXCR3B \\
\hline CXCL11 & I-TAC & $\begin{array}{l}\text { CXCR3, CXCR3B } \\
\text { CXCR7 }\end{array}$ \\
\hline CXCL12 & SDF- $1 \alpha / \beta$ & CXCR4, CXCR7 \\
\hline CXCL13 & $\mathrm{BLC}, \mathrm{BCA}-1$ & CXCR5 \\
\hline CXCL14 & BRAK, Bolckine & Unknown \\
\hline CXCL15 & Unknown & Unknown \\
\hline CXCL16 & & CXCR6 \\
\hline CXCL17 & DMC & Unknown \\
\hline \multicolumn{3}{|c|}{ CC chemokines } \\
\hline CCL1 & I-309 & CCR8 \\
\hline CCL2 & MCP-1/MCAF/TDCF & CCR2 \\
\hline CCL3 & MIP-1 $1 \alpha / L D 78 \alpha$ & CCR1, CCR5 \\
\hline CCL3L1 & LD78 $\beta$ & \\
\hline CCL3L3 & LD78 $\beta$ & \\
\hline CCL4 & MIP-1 $\beta$ & CCR5 \\
\hline CCL4L1 & AT744.2 & \\
\hline \multicolumn{3}{|l|}{ CCL4L2 } \\
\hline CCL5 & RANTES & $\begin{array}{l}\text { CCR } 1, \text { CCR3, } \\
\text { CCR5 }\end{array}$ \\
\hline CCL7 & MCP-3 & $\begin{array}{l}\text { CCR1, CCR2, } \\
\text { CCR3 }\end{array}$ \\
\hline CCL8 & MCP-2 & $\begin{array}{l}\text { CCR1, CCR2, } \\
\text { CCR3, CCR5 }\end{array}$ \\
\hline CCL11 & Eotaxin & CCR3 \\
\hline CCL13 & $\mathrm{MCP}-4$ & $\begin{array}{l}\text { CCR1, CCR2, } \\
\text { CCR3 }\end{array}$ \\
\hline CCL14 & $\mathrm{HCC}-1$ & CCR1 \\
\hline CCL15 & HCC-2/LKN1/MIP-1 $\gamma$ & CCR1, CCR3 \\
\hline CCL16 & HCC-4/LEC/LCC-1 & $\begin{array}{l}\text { CCR } 1, \text { CCR } 2, \\
\text { CCR } 5\end{array}$ \\
\hline CCL17 & TARC & CCR4 \\
\hline CCL18 & $\begin{array}{l}\text { DC-CK 1/PARC/ } \\
\text { AMAC-1 }\end{array}$ & Unknown \\
\hline CCL19 & $\begin{array}{l}\text { MIP-3 } \beta / E L C / \\
\text { exodus-3 }\end{array}$ & CCR7 \\
\hline CCL20 & $\begin{array}{l}\text { MIP-3 } \alpha / \text { LARC/ } \\
\text { exodus- } 1\end{array}$ & CCR6 \\
\hline CCL21 & $\begin{array}{l}\text { SLC/6Ckine/SLC/ } \\
\text { exodus-2 }\end{array}$ & CCR7 \\
\hline CCL22 & MDC/STCP-1 & CCR4 \\
\hline CCL23 & MPIF/CK $\beta 8 / C K \beta 8-1$ & CCR1 \\
\hline CCL24 & Eotaxin-2/MPIF-2 & CCR3 \\
\hline CCL25 & TECK & CCR9 \\
\hline CCL26 & Eotaxin-3 & CCR3 \\
\hline CCL27 & CTACK/ILC & CCR10 \\
\hline CCL28 & MEC & CCR3, CCR10 \\
\hline
\end{tabular}

Table 1 continued

\begin{tabular}{lll}
$\begin{array}{l}\text { New } \\
\text { nomenclature }\end{array}$ & Ligand & Receptor(s) \\
\hline $\begin{array}{l}\text { C chemokines } \\
\text { XCL1 }\end{array}$ & Lymphotactin/ATAC/ \\
SCM-1 $\alpha$ & XCR1 \\
XCL2 & SCM-1 $\beta$ & XCR1 \\
CX3C chemokines & \\
CX ${ }_{3}$ CL1 & Fractalkine & CX3CR1 \\
\hline
\end{tabular}

amino-terminal cysteine residues motif into CC, CXC, $\mathrm{CX} 3 \mathrm{C}$, and $\mathrm{C}$ chemokines (Table 1). There is a remarkable redundancy within chemokines, with multiple chemokines binding to the same receptor and multiple receptors binding the same chemokine (Fig. 1). Chemokines interact with G-protein-coupled receptors. These are composed of ten CCR family members, seven CXCR family members, and other receptors (XCR1, CCRL1 and 2, and CX3CR1). The chemokine system also includes three decoy receptors. These receptors bind ligands with high affinity, but do not elicit signal transduction. The D6, Duffy antigen receptor for chemokines (DARC) and CCX-CKR (ChemoCentryx, chemokine receptor), are specialized receptors for chemokine sequestration acting to regulate chemokine bioavailability and compete with active receptors (Peiper et al. 1995, Nibbs et al. 1997, Gosling et al. 2000). Evidence exists that a chemokine monomer is sufficient to bind and activate a chemokine receptor and induce efficient leukocyte responses (Rajarathnam et al. 1994, Proudfoot et al. 2003). Nevertheless, in vivo data indicate that for some chemokines, such as CCL2, CCL4, CCL5, and CXCL10, the formation of oligomers enhances leukocyte recruitment (Proudfoot et al. 2003, Campanella et al. 2006). At chemokine-rich sites of inflammation, it is possible that chemokines heterodimerize. Studies have shown that such heteromeric chemokines have considerable synergism, strongly enhancing leukocyte migration. The inflammatory chemokine CXCL8, for example, can potentiate responses induced by CCL2 and CXCL12, which act on CCR1 and CXCR4 respectively, but not with CCL21, which triggers responses through CCR7 (Gouwy et al. 2005, 2008). In response to chemokines, chemokine receptors induce a cascade of signals, which can differ between tissues, cell types, and physiologic or pathologic conditions. In particular, a cascade of downstream signals takes place, including calcium mobilization and the activation of extracellular signal-regulated kinases 1 and 2 (ERK1 and ERK2), p38 mitogen-activated protein kinase (p38 MAPK), 


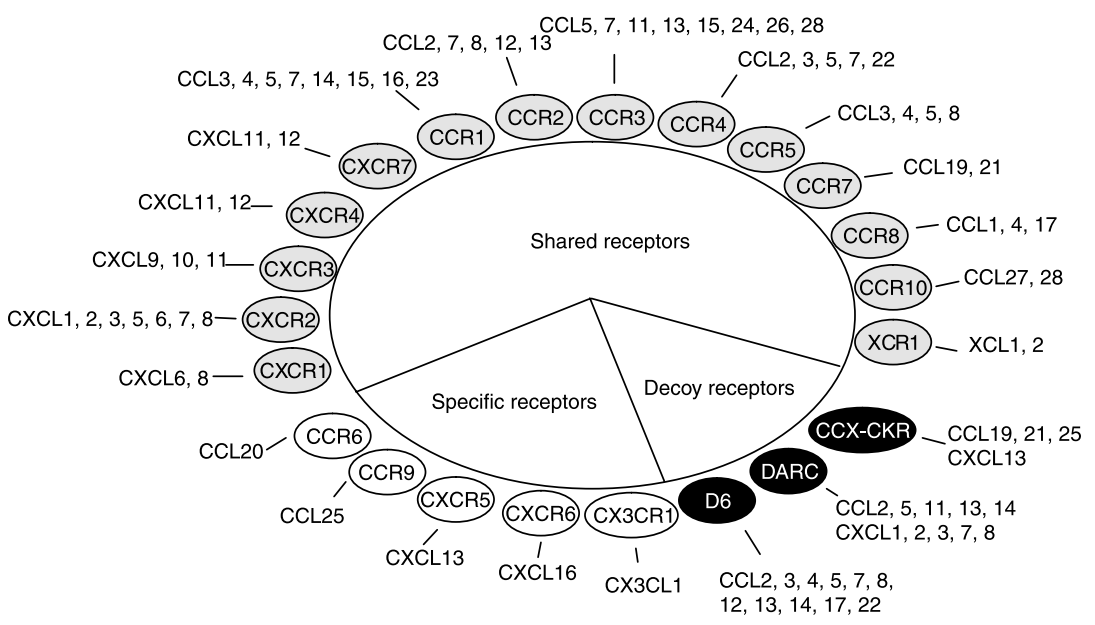

Figure 1 Chemokine members and their cognate receptors.

phospholipase-C $\beta$, phosphatidylinositol 3-kinase (PI3K), RAS, the RHO family of GTPases, p21-activated kinase (PAK), and NF- $\kappa$ B (Rossi \& Zlotnik 2000, Richmond 2002).

\section{Chemokines and chemokine receptors: correlation with $\mathrm{PCa}$ disease progression}

PCa typically develops through several steps, the first being the transition from normal prostate to $\mathrm{BPH}$ (Bostwick et al. 2004). During the transitions from normal to $\mathrm{BPH}$ and from $\mathrm{BPH}$ to $\mathrm{PCa}$, a number of chemokines and chemokine receptors display variations in their expression. Moreover, it is important to notice that chemokines are produced by a variety of cells, comprising cancer cells but also stromal cells such as cancer-associated fibroblasts (CAFs), endothelial cells, or infiltrating cells (macrophages, lymphocytes), which is summarized in Table 2. Most of the work on chemokines in PCa has focused on the chemokines CXCL8, CXCL12, and CCL2.

Analysis by immunohistochemistry of normal human prostate has revealed that CXCL8 is weakly expressed and present at the apical membrane of epithelial cells (Murphy et al. 2005). Concerning the transition from normal to $\mathrm{BPH}$, and based on the study of cell lines, it appears that the levels of proangiogenic chemokine CXCL8 are higher in BPH compared with normal prostate, which is correlated with an increased number of myofibroblasts in the stroma of BPH (Schauer et al. 2008b). BPH nodules exhibit epithelial CXCL8 staining, in addition to elevated smooth muscle $\alpha$-actin, reduced calponin, and altered deposition of tenascin-C relative to normal prostate zone tissue (Schauer et al. 2008b).
This suggests that a reactive stroma pattern is correlated with an increase in CXCL8 levels in the adjacent epithelium.

The balance of chemokines is also altered with the progression of $\mathrm{PCa}$ (Fig. 2). In situ hybridization experiments have shown that CXCL8 RNA levels increase with the Gleason score of prostate tumors (Uehara et al. 2005). In PCa tissues, CXCL8 staining, as well as that of CXCR1 and CXCR2, is circumferential in high-grade tumors (Murphy et al. 2005). The localization of CXCL8 is somewhat controversial as another study has reported that CXCL8 is expressed by the neuroendocrine cells of human PCa (Huang et al. 2005). This discrepancy could arise from the use of different antibodies to detect CXCL8. The same study also observed an increased expression of CXCR1 in epithelial cells of PCas compared with normal prostate. Moreover, CXCR2 is present in neuroendocrine cells (Huang et al. 2005). CXCL8 protein can also be detected in the serum of patients. Seric CXCL8 levels are elevated in patients with bone metastasis compared with patients with localized disease (Veltri et al. 1999, Lehrer et al. 2004).

Immunohistochemical analysis has revealed CXCL8 in benign areas adjacent to the tumor in PCa patients with recurrence compared to tissue from patients who have not recurred (Caruso et al. 2008). CXCL8 staining predicts recurrence with a high sensitivity and specificity (Caruso et al. 2008).

CXCL1, another chemokine binding to CXCR2, is lower in $\mathrm{BPH}$ compared with $\mathrm{PCa}$, whereas the angiostatic chemokines CXCL10 and CXCL11 are more abundant in BPH compared with PCa (Ferrer et al. 1998, Nagpal et al. 2006). This is confirmed with cell lines in which CXCL1, CXCL3, CXCL5, 
Table 2 Localization of chemokines and chemokine receptors

\begin{tabular}{|c|c|c|c|c|c|c|}
\hline & $\begin{array}{l}\text { Epithelial } \\
\text { cells }\end{array}$ & $\begin{array}{l}\text { Neuroendocrine } \\
\text { cells }\end{array}$ & CAFs & $\begin{array}{c}\text { Endothelial } \\
\text { cells }\end{array}$ & $\begin{array}{l}\text { Infiltrating } \\
\text { cells }\end{array}$ & References \\
\hline CXCL1 & + & & & & & Engl (2006a), Lu (2007a) \\
\hline CXCL2 & + & & + & & & Engl (2006a), Begley et al. (2008a) \\
\hline CXCL3 & + & & & & & Engl (2006a) \\
\hline CXCL5 & + & & + & & & $\begin{array}{l}\text { Engl (2006a), Lu (2007a), Begley et al. } \\
\qquad(2008 a)\end{array}$ \\
\hline CXCL6 & + & & + & & & Begley et al. (2005), Engl (2006a) \\
\hline CXCL8 & + & + & & & & $\begin{array}{l}\text { Huang (2005), Murphy (2005), Schauer et al. } \\
(2008 b)\end{array}$ \\
\hline CXCL12 & + & & ++ & & & $\begin{array}{l}\text { Begley (2005), Berquin (2005), Begley et al. } \\
\text { (2008a) }\end{array}$ \\
\hline CXCL14 & + & & & & & Schwartze (2005) \\
\hline CCL2 & & & & + & & Mazuchelli (1996), Loberg (2006), Lu (2006) \\
\hline CCL20 & + & & & & & Ghadjar (2008) \\
\hline CX3CL1 & & & & + & & Shulby (2004), Jamieson (2008) \\
\hline CXCR1 & + & & & & & Huang (2005) \\
\hline CXCR2 & & + & & & & Huang (2005) \\
\hline CXCR4 & + & & & & & Begley (2005) \\
\hline CXCR7 & + & & & & & Wang (2008) \\
\hline CCR2 & + & & & & & Mazuchelli (1996), Loberg (2006), Lu (2006) \\
\hline CCR6 & + & & & & & Ghadjar (2008) \\
\hline CX3CR 1 & + & & & & & Shulby (2004), Jamieson (2008) \\
\hline
\end{tabular}

CAFs, cancer associated fibroblasts.

and CXCL6 levels are higher in more aggressive cell lines such as DU-145 and PC3 compared with LNCaP cells (Aalinkeel et al. 2004, Engl et al. 2006a, Lu et al. 2007a). CXCL5 levels also correlate with PCa progression and with inflammatory mediator infiltration (Begley et al. 2008b). In the same line, CXCL14 levels increase with Gleason score (Schwarze et al. 2005).

A large body of work has focused on CXCL12 and one of its receptors, CXCR4. The expression levels of CXCL12 and its receptor CXCR4 are higher in human $\mathrm{PCa}$ tissues than those of BPH tissues (Zhang et al. 2008). It is worth mentioning that the levels of CXCR4 found at the surface of PCa cells are relatively low, but sufficient to elicit biological responses, in particular, the adhesion of PCa cells to endothelial cells or extracellular matrix through $\alpha 5$ and $\beta 3$ integrins (Engl et al. 2006b). CXCR4 expression does not correlate with pathological grade, bone metastasis, or clinical response to hormonal therapy (Akashi et al. 2008). However, patients with a high expression of CXCR4 in tumors have a lower survival expectation than those with low expression of CXCR4 (Akashi et al. 2008). On the other hand, the second receptor of CXCL12, CXCR7, displays levels that correlate with tumor progression (Wang et al. 2008). In mice, CXCL12 is mainly seen in stromal cells and the extracellular matrix rather than in epithelial cells (Berquin et al. 2005).
In epithelial cells, the staining of CXCL12 is apical (Berquin et al. 2005). Interestingly, CXCL12 levels decrease in stromal cells and increase in epithelial cells of the prostate of PTEN-deficient mice compared with wild-type mice, whereas CXCR4 levels are up-regulated in PTEN-deficient mice compared with wild-type mice (Berquin et al. 2005). In addition, CXCL12 is produced by osteoblasts (Taichman et al. 2002).

Chemokines and their receptors are regulated through tumor progression. The more aggressive types of PCa cell lines express higher levels of CCR2 compared with less aggressive cells (Lu et al. 2007b). In addition, CCR2 RNA and protein levels increase in metastatic PCas compared with localized PCas (Lu et al. 2007b). CCR6 levels are correlated with more aggressive PCas of higher Gleason score and exhibiting higher lymph node metastasis (Ghadjar et al. 2008). However, CCR6 and CCL20 levels do not correlate. CXCR6 expression is high in prostate tumors, whereas its ligand CXCL16 is expressed by osteocytes (Hu et al. 2008).

Interestingly, chemokines and their receptors could also contribute to the variable incidence of $\mathrm{PCa}$ in the world. Indeed, the incidence and mortality rates of $\mathrm{PCa}$ are significantly higher in African-American men when compared with European-American men. A comparative microarray analysis of chemokine 

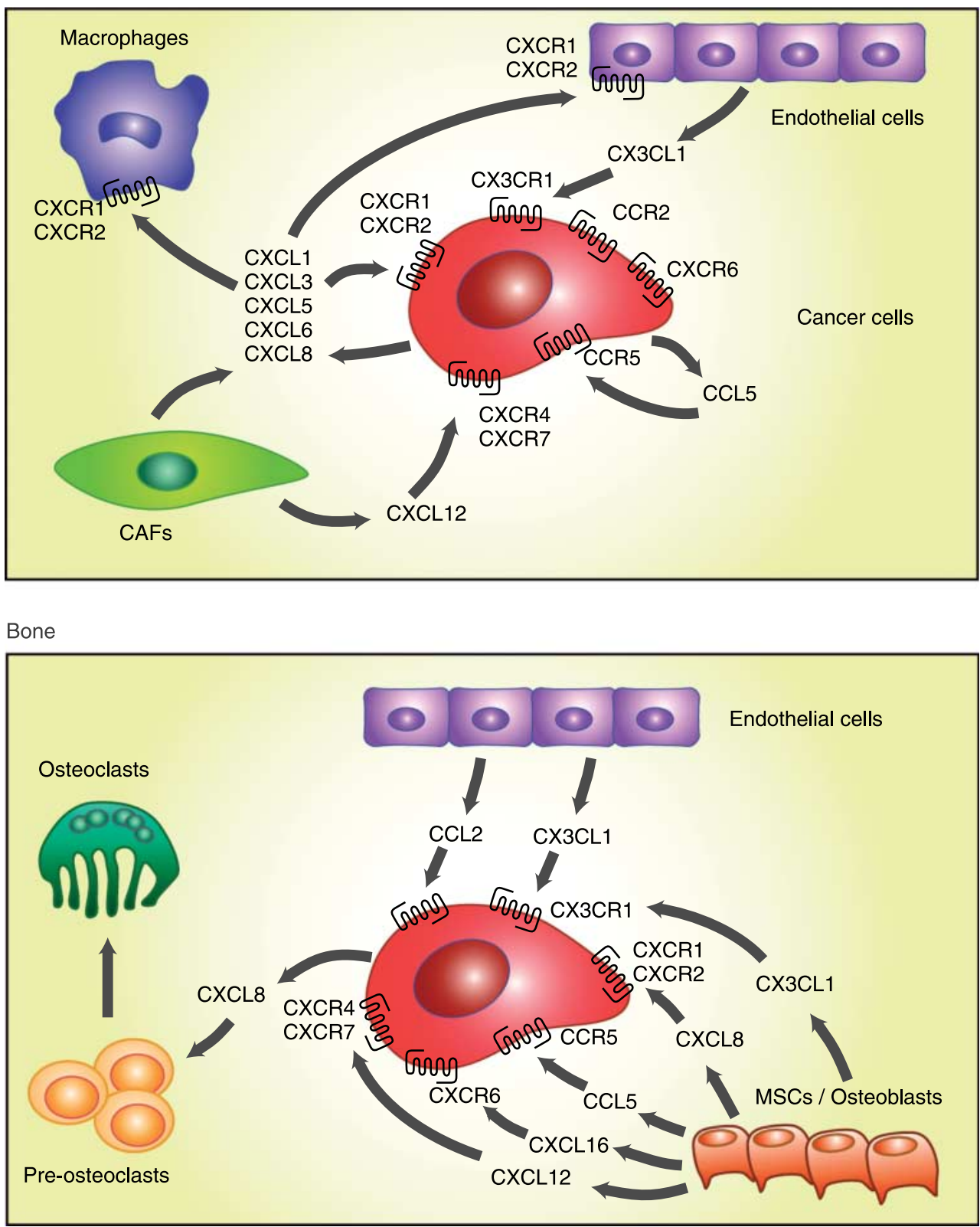

Figure 2 The network of chemokines and chemokines receptors in prostate and bone. Upper panel: prostate situation. Cancer cells express chemokines and chemokine receptors and interact with cancer-associated fibroblasts (CAFs) and endothelial cells. The production of chemokine by cancer cells and stromal cells leads to leukocyte infiltration, including macrophage recruitment. Lower panel: bone situation. Bone is a typical site of metastasis for prostate cancers. Cancer cells are attracted to the bone by chemokines produced by endothelial cells, mesenchymal stromal cells (MSCs), and osteoblasts.

expression profiles of patients with primary prostate tumors showed that CCL5, CCR7, and CXCR4 were expressed at higher levels in African-American patients compared with European-American patients (Wallace et al. 2008).

A number of chemokines appear to be mainly produced by stromal cells. Human prostatic CAF can elicit malignant changes in initiated but nontumorigenic human prostatic epithelium and, in particular, CAFs are able to induce the growth of a human prostatic epithelial cell line (BPH-1; Olumi et al. 1999, Barclay et al. 2005). The analysis of the interactions of $\mathrm{BPH}$ cells with CAFs reveals that CAFs secrete transforming growth factor (TGF) $\beta 1$, which inhibits cellular growth 
in vitro but is necessary for $\mathrm{BPH}$ growth in vivo. Indeed, TGF $\beta 1$ increases the level of CXCR4 on BPH cells. CAFs also secrete high levels of CXCL12, the ligand of CXCR4, which in turn stimulate BPH growth in vivo (Ao et al. 2007). In addition, aging prostate stromal fibroblasts secrete higher levels of CXCL12 compared with young fibroblasts isolated from the prostate of younger men (Begley et al. 2005). Similar observations have been reported for CXCL1, CXCL2, CXCL5, and CXCL6 (Begley et al. 2008a). These chemokines weakly stimulate the proliferation of stromal fibroblasts (Begley et al. 2008a).

Other chemokines are produced mainly by endothelial cells. This is the case for CCL2, which is mainly expressed by human bone marrow endothelial cells (HBME), and at a lesser extent by PCa cells (Mazzucchelli et al. 1996, Loberg et al. 2006, Lu et al. 2006). Human PCa cells express CX3CR1, whereas its ligand, CXC3CL1, is produced by HBME and differentiated osteoblasts (Shulby et al. 2004). Human normal prostate epithelial cells (PrEc) weakly express CX3CR1 (Jamieson et al. 2008). Osteoblasts, stromal, and mesenchymal cells derived from human bone marrow aspirates express the cell-bound form of fractalkine, whereas the soluble form of the chemokine is detected in bone marrow supernatants (Jamieson et al. 2008), reflecting the emerging roles of mesenchymal stromal cells and chemokines in cancer (Lazennec \& Jorgensen 2008).

Polymorphism of some chemokine genes is altered in $\mathrm{PCa}$, which could potentially correlate with the expression levels of chemokines. A single nucleotide polymorphism of CXCL12 G801A has been reported. It appears that the genotype GA + AA is increased in $\mathrm{PCa}$ patients compared with healthy controls (Hirata et al. 2007). In addition, the genotype AA is more frequent in metastatic patients compared with nonmetastatic patients (Hirata et al. 2007). On the other hand, no strong association between the SNPs for CXCL8-251 $(\mathrm{A} \rightarrow \mathrm{T})$, CXCR1+860 $(\mathrm{C} \rightarrow \mathrm{G})$, and CXCR2-1010 $(\mathrm{A} \rightarrow \mathrm{G})$ and either the subsequent risk of PCa or individual prognostic factors among cases have been found in another study (Yang et al. 2006).

\section{In vitro and in vivo effects of chemokines: growth, invasiveness, metastasis, angiogenesis, and leukocyte infiltration}

Chemokines and their cognate receptors have been shown to regulate multiple events in carcinogenesis including growth, invasion, metastasis, angiogenesis, and leukocyte infiltration. For clarity, we have classified chemokine action by subfamily.

\section{CXC chemokines}

In vitro, CXCL12 can stimulate the invasion of $\mathrm{PCa}$ cells, while the CXCR4 antagonist AMD3100 inhibits invasiveness (Zhang et al. 2008). The stimulation of invasion by CXCL12 involves in particular an induction of the matrix metalloprotease MMP-9, through an activation of PI3K and MAPK pathways (Chinni et al. 2006). The levels of CXCL12 in human and mouse tissues are higher in the organs, which are a site of metastasis for PCa cells (i.e. bone, liver, and kidney), compared with tissues, which rarely develop metastases following PCa (i.e. lung, tongue, and eye; Sun et al. 2005). CXCL12 is localized to the metaphysis of the long bones, nearest the growth plate, but not in the center of the bone marrow (Sun et al. 2005). In addition, CXCL12 increases the adhesion of PCa cells to an endothelial cell monolayer and to immobilized fibronectin, laminin, and collagen (Kukreja et al. 2005, Engl et al. 2006b), and to osteosarcoma cells (Taichman et al. 2002). This may occur through an up-regulation of $\alpha 5$ and $\beta 3$ integrins (Engl et al. 2006b). CXCL12 also increases transendothelial migration (Taichman et al. 2002). CXCL12 triggers an angiogenic switch, through the up-regulation of vascular endothelial growth factor (VEGF) and CXCL8, as demonstrated by the use of siRNA against CXCR4 (Wang et al. 2005). Interestingly, CXCL12 down-regulates the glycolytic enzyme phosphoglycerate kinase 1 , which is a negative regulator of VEGF and CXCL8 expression (Wang et al. 2007).

CXCL8 enhances in vitro growth, motility, and invasion, as well as MMP-9 and VEGF production (Reiland et al. 1999, Inoue et al. 2000, Seaton et al. 2008). In vivo, the stable transfection of CXCL8 in PCa cells stimulates tumor growth, probably through an increased angiogenesis (Inoue et al. 2000, Lee et al. 2004, Araki et al. 2007). Similar results have been obtained with clones of PC-3 cells expressing various amounts of CXCL8: clones producing more CXCL8 are more tumorigenic in vivo, lead to the development of more vascularized tumors and generate lymph node metastasis with a high incidence (Kim et al. 2001). On the other hand, blocking antibodies against CXCL8 can prevent prostate tumor growth in SCID mice (Moore et al. 1999). In vitro experiments have shown that CXCL8 could stimulate the differentiation of human bone marrow mononuclear cells into osteoclast-like cells. Similar effects could be obtained with PCa cell-conditioned medium. Interestingly, the effects of cancer cell-conditioned medium can be inhibited by CCL2 antibodies, which suggest that both CCL2 and CXCL8 promote osteoclastogenesis (Lu et al. 2007a). 
Other chemokines with the ability to bind to CXCR2 might be involved in PCa. Indeed, CXCL1 is also able to stimulate in vitro invasion and in vivo growth of $\mathrm{PCa}$ cells (Moore et al. 1999, Inoue et al. 2000). Mouse CXCL1 plays a role in prostate hyperplasia. Indeed, transgenic mice expressing keratinocyte-derived chemokine (KC) display prostate hyperplasia with increased acini diameter and higher Ki67 staining (Schauer et al. 2008a). In the same line, CXCL5 (which also binds CXCR2) is able to stimulate the growth of PCa cell lines in vitro (Begley et al. 2008b). Similarly, in athymic mice, overexpression of CXCL8 in human PrEc implanted subcutaneously leads to hyperplasia, but no change of apoptotic index (Schauer et al. 2008a). However, the increase in Ki67 staining of PrEc is not observed with the single injection of PrEc, but only when PrEc-CXCL8 are coinjected with prostate stromal cells (Schauer et al. 2008a).

\section{CCL chemokines}

CCL2 is able to stimulate PCa cell migration and proliferation in vitro (Loberg et al. 2006, Lu et al. 2006). Neutralization of CCL2 with antibodies inhibits tumor growth in a xenograft model using $\mathrm{VCaP}$ cells (Loberg et al. 2007). In addition, inhibition of CCL2 leads to a reduction of macrophage infiltration in the tumor (Loberg et al. 2007). Interestingly, the coinjection of U937 promonocytic cells with PC3 cells increases tumor growth and angiogenesis, probably through an increased expression of CCL2 (Craig et al. 2008).

CCL5 and its receptor CCR5 are expressed by PCa cell lines (Vaday et al. 2006). CCL5 stimulates both the proliferation and invasion of PCa cells in vitro (Vaday et al. 2006).

\section{CX3CL1}

The adhesion of PCa cells to bone marrow endothelial cells and their migration toward human osteoblast are reduced in flow conditions by neutralizing antibodies against CX3CL1 (Shulby et al. 2004).

\section{Receptors}

The roles of CXCR2 and CXCR3 in carcinogenesis have been investigated in the model of TRAMP mice. These mice, which express SV40 T antigen under the control of probasin promoter, develop spontaneous prostate tumors (Gingrich \& Greenberg 1996). The breeding of TRAMP mice with CXCR2 KO mice leads to the development of smaller and less vascularized tumors in TRAMP/CXCR2 $(-/-)$ mice compared with TRAMP/CXCR2 $(+/+)$ mice (Shen et al. 2006a). On the other hand, the same type of experiments with TRAMP and CXCR3 KO mice showed that CXCR3 was enhancing tumor development and vascularization (Shen et al. 2006a), suggesting that CXCR2 and CXCR3 have opposite roles on $\mathrm{PCa}$ development in mice.

In the same line, the role of the DARC, which is a decoy receptor for a number of ELR + CXC chemokines, has been investigated (Szabo et al. 1995). DARC is mainly expressed by erythrocytes and endothelial cells. In vitro, erythrocytes from wild-type mice but not from DARC-deficient mice are able to clear CXCL1 and CXCL8 produced by PCa cells (Shen et al. 2006b). Cross-breeding of DARC KO mice with TRAMP mice leads to an increase in tumor growth and vascularization compared with TRAMP mice (Shen et al. 2006b). In addition, KC and MIP-2 levels are elevated in the tumor of TRAMP/DARC $-1-$ mice (Shen et al. 2006b). This mechanism could account at least in part for the higher incidence of $\mathrm{PCa}$ in the African-American population, which frequently displays a lack of DARC expression on erythrocytes.

Concerning CXCL12 receptors, in vivo, the neutralization of CXCR4 with antibodies reduces the development of bone metastasis, following intracardiac injection of the cells (Sun et al. 2005). In addition, the growth of PCa cells directly injected in the tibia is reduced by the i.p. injection of CXCR4 antibodies (Sun et al. 2005).

Knockdown of CXCR7, the second receptor of CXCL12, in PC-3 or LNCap C4-2 cells slightly reduces cell growth in vitro (Wang et al. 2008). On the other hand, overexpression of CXCR7 in the same cells enhances their proliferation (Wang et al. 2008). Moreover, CXCR7 can prevent apoptosis and increase in vitro invasion (Wang et al. 2008). In vivo, CXCR7 silencing strongly reduced the tumor growth of C4-2B cells (Wang et al. 2008).

\section{Do chemokines modulate hormone escape?}

Hormone-refractory PCas are of particular concern for clinicians as they exhibit a higher aggressiveness and lack of efficient treatment (Taplin 2007, Devlin \& Mudryj 2009). Several groups have begun to investigate whether chemokines could be involved in this phenomenon. To date, the only chemokine identified in such phenomenon is CXCL8, but conflicting results have been published. Indeed, the stable transfection of CXCL8 cDNA in AR-positive PCa cells reduces their dependence to androgens and reduces the growth inhibition observed in the presence of anti-androgens as bicalutamide, through CXCR1 (Araki et al. 2007). 
On the other hand, Seaton et al. (2008) reported that CXCL8 could enhance the proliferation of cancer cells, but this could not be observed in the presence of bicalutamide. Another difference with the study from Araki was that CXCL8 action occurred through CXCR2 (Seaton et al. 2008). CXCL8 action on AR activity is also controversial. CXCL8 reduces AR and PSA levels of LNCaP and LAPC4 cells according to Araki et al. (2007), but Seaton et al. (2008) showed that CXCL8 not only increases AR and PSA RNA and protein levels in LNCaP and 22Rv1 cells, but also increases AR activity. This finding was also confirmed by Lee et al. (2004) who showed that CXCL8 activates the $\mathrm{AR}$ and confers androgen-independent growth to PCa cells. CXCL8 increases the recruitment of AR to PSA promoter in LNCaP cells (Lee et al. 2004). CXCL8 also increased the survival of PCa cells treated with the drug docetaxel (Araki et al. 2007).

\section{Mechanisms of control of expression of chemokines and chemokine receptors}

So far, the signals and the mechanism of regulation of chemokines in $\mathrm{PCa}$ remain poorly studied. Most studies have analyzed the effects of nuclear receptors such as $A R$ and vitamin $D_{3}$ receptor (VDR) on chemokine expression.

CXCL8 is a target of VDR in PCa cells. Addition of 1 $\alpha, 25$-dihydroxyvitamin $\mathrm{D}_{3}\left(\mathrm{VD}_{3}\right)$ down-regulates CXCL8 levels, through NF- $\kappa \mathrm{B}$ inhibition, by blocking p65 nuclear translocation (Bao et al. 2006). Recently, the role of RelB and the alternative NF- $\kappa \mathrm{B}$ pathway leading to overexpression of IL-8 in PCa have been demonstrated (Xu et al. 2009).

Similarly, Penna et al. (2008) reported that the VDR agonist elocalcitol inhibits CXCL8 production induced by inflammatory cytokines in BPH and CXCL8induced proliferation of these cells.

CX3CL1 is the target of another nuclear receptor, AR. The androgen dihydrotestosterone increases the cleavage of CX3CL1 from the plasma membrane of bone, but does not cleave the cell-bound form of CX3CL1 from HBME (Jamieson et al. 2008). The extravasation of PCa cells expressing CX3CR1 could be enhanced by androgens, through free fractalkine. The ability of cancer cells to adhere to the bone marrow endothelium would be unaltered (Jamieson et al. 2008).

The reintroduction of $\mathrm{AR}$ in the AR-negative DU-145 PCa cell lines leads to a down-regulation of CXCR4 and CCR1 RNA levels and the modified cell lines became unresponsive in terms of in vitro invasion to CXCL12 and CCL3, the respective ligands of CXCR4 and CCR1 (Akashi et al. 2006).

\section{Conclusion}

Chemokines and their receptors show differential expression along with $\mathrm{PCa}$ progression. It is interesting to note that numerous chemokines are involved in these different steps, even though most of the current work has explored only a small part of the chemokine superfamily. Based on the fact that chemokines are expressed by different types of cells, not only in the prostate but also in distant organs, targets of metastasis, this draws a fine network of interactions between these factors. Both the stromal and epithelial compartments are involved in terms of chemokine production. Chemokines affect not only angiogenesis but also other processes such as proliferation, hormone-escape, and leukocyte infiltration. Chemokines and their receptors constitute not only novel markers of $\mathrm{PCa}$ but also possible targets for future therapies.

\section{Declaration of interest}

There is no conflict of interest that could be perceived as prejudicing the impartiality of the research reported.

\section{Funding}

David Vindrieux was a recipient of La Ligue contre le Cancer. Pauline Escobar is a recipient of ARTP (Association de Recherche sur les Tumeurs de la Prostate).

\section{Acknowledgements}

We thank J L Pasquier for iconography and Dr C Vogel for helpful advice.

\section{References}

Aalinkeel R, Nair MP, Sufrin G, Mahajan SD, Chadha KC, Chawda RP \& Schwartz SA 2004 Gene expression of angiogenic factors correlates with metastatic potential of prostate cancer cells. Cancer Research 64 5311-5321.

Akashi T, Koizumi K, Nagakawa O, Fuse H \& Saiki I 2006 Androgen receptor negatively influences the expression of chemokine receptors (CXCR4, CCR1) and ligandmediated migration in prostate cancer DU-145. Oncology Reports 16 831-836.

Akashi T, Koizumi K, Tsuneyama K, Saiki I, Takano Y \& Fuse H 2008 Chemokine receptor CXCR4 expression and prognosis in patients with metastatic prostate cancer. Cancer Science 99 539-542.

Ali S \& Lazennec G 2007 Chemokines: novel targets for breast cancer metastasis. Cancer Metastasis Reviews 26 401-420.

Ao M, Franco OE, Park D, Raman D, Williams K \& Hayward SW 2007 Cross-talk between paracrine-acting cytokine 
and chemokine pathways promotes malignancy in benign human prostatic epithelium. Cancer Research 67 4244-4253.

Araki S, Omori Y, Lyn D, Singh RK, Meinbach DM, Sandman Y, Lokeshwar VB \& Lokeshwar BL 2007 Interleukin- 8 is a molecular determinant of androgen independence and progression in prostate cancer. Cancer Research 67 6854-6862.

Bao BY, Yao J \& Lee YF 2006 1 $\propto$, 25-dihydroxyvitamin $\mathrm{D}_{3}$ suppresses interleukin-8-mediated prostate cancer cell angiogenesis. Carcinogenesis 27 1883-1893.

Barclay WW, Woodruff RD, Hall MC \& Cramer SD 2005 A system for studying epithelial-stromal interactions reveals distinct inductive abilities of stromal cells from benign prostatic hyperplasia and prostate cancer. Endocrinology 146 13-18.

Begley L, Monteleon C, Shah RB, Macdonald JW \& Macoska JA 2005 CXCL12 overexpression and secretion by aging fibroblasts enhance human prostate epithelial proliferation in vitro. Aging Cell 4 291-298.

Begley LA, Kasina S, MacDonald J \& Macoska JA 2008 a The inflammatory microenvironment of the aging prostate facilitates cellular proliferation and hypertrophy. Cytokine 43 194-199.

Begley LA, Kasina S, Mehra R, Adsule S, Admon AJ, Lonigro RJ, Chinnaiyan AM \& Macoska JA 2008b CXCL5 promotes prostate cancer progression. Neoplasia 10 244-254.

Berquin IM, Min Y, Wu R, Wu H \& Chen YQ 2005 Expression signature of the mouse prostate. Journal of Biological Chemistry 280 36442-36451.

Bostwick DG, Burke HB, Djakiew D, Euling S, Ho SM, Landolph J, Morrison H, Sonawane B, Shifflett T, Waters DJ et al. 2004 Human prostate cancer risk factors. Cancer 101 2371-2490.

Campanella GS, Grimm J, Manice LA, Colvin RA, Medoff BD, Wojtkiewicz GR, Weissleder R \& Luster AD 2006 Oligomerization of CXCL10 is necessary for endothelial cell presentation and in vivo activity. Journal of Immunology 177 6991-6998.

Caruso DJ, Carmack AJK, Lokeshwar VB, Duncan RC, Soloway MS \& Lokeshwar BL 2008 Osteopontin and interleukin-8 expression is independently associated with prostate cancer recurrence. Clinical Cancer Research 14 4111-4118.

Chinni SR, Sivalogan S, Dong Z, Filho JC, Deng X, Bonfil RD \& Cher ML 2006 CXCL12/CXCR4 signaling activates Akt-1 and MMP-9 expression in prostate cancer cells: the role of bone microenvironment-associated CXCL12. Prostate 66 32-48.

Craig M, Ying C \& Loberg RD 2008 Co-inoculation of prostate cancer cells with U937 enhances tumor growth and angiogenesis in vivo. Journal of Cellular Biochemistry 103 1-8.

Devlin HL \& Mudryj M 2009 Progression of prostate cancer: multiple pathways to androgen independence. Cancer Letters 274 177-186.
Dowsland MH, Harvey JR, Lennard TW, Kirby JA \& Ali S 2003 Chemokines, breast cancer: a gateway to revolutionary targeted cancer treatments? Current Medicinal Chemistry 10 579-592.

Engl T, Relja B, Blumenberg C, Muller I, Ringel EM, Beecken WD, Jonas D \& Blaheta RA 2006a Prostate tumor CXC-chemokine profile correlates with cell adhesion to endothelium and extracellular matrix. Life Sciences 78 1784-1793.

Engl T, Relja B, Marian D, Blumenberg C, Muller I, Beecken WD, Jones J, Ringel EM, Bereiter-Hahn J, Jonas D et al. 2006b CXCR4 chemokine receptor mediates prostate tumor cell adhesion through $\alpha 5$ and $\beta 3$ integrins. Neoplasia 8 290-301.

Ferrer FA, Miller LJ, Andrawis RI, Kurtzman SH, Albertsen PC, Laudone VP \& Kreutzer DL 1998 Angiogenesis and prostate cancer: in vivo and in vitro expression of angiogenesis factors by prostate cancer cells. Urology 51 161-167.

Ghadjar P, Loddenkemper C, Coupland SE, Stroux A, Noutsias M, Thiel E, Christoph F, Miller K,

Scheibenbogen C \& Keilholz U 2008 Chemokine receptor CCR6 expression level and aggressiveness of prostate cancer. Journal of Cancer Research and Clinical Oncology 134 1181-1189.

Gingrich JR \& Greenberg NM 1996 A transgenic mouse prostate cancer model. Toxicologic Pathology 24 502-504.

Gosling J, Dairaghi DJ, Wang Y, Hanley M, Talbot D, Miao Z \& Schall TJ 2000 Cutting edge: identification of a novel chemokine receptor that binds dendritic cell- and T cell-active chemokines including ELC, SLC, and TECK. Journal of Immunology 164 2851-2856.

Gouwy M, Struyf S, Proost P \& Van Damme J 2005 Synergy in cytokine and chemokine networks amplifies the inflammatory response. Cytokine \& Growth Factor Reviews 16 561-580.

Gouwy M, Struyf S, Noppen S, Schutyser E, Springael JY, Parmentier M, Proost P \& Van Damme J 2008 Synergy between coproduced $\mathrm{CC}$ and $\mathrm{CXC}$ chemokines in monocyte chemotaxis through receptor-mediated events. Molecular Pharmacology 74 485-495.

Hirata H, Hinoda Y, Kikuno N, Kawamoto K, Dahiya AV, Suehiro Y, Tanaka Y \& Dahiya R 2007 CXCL12 G801A polymorphism is a risk factor for sporadic prostate cancer susceptibility. Clinical Cancer Research 13 5056-5062.

Hu W, Zhen X, Xiong B, Wang B, Zhang W \& Zhou W 2008 CXCR6 is expressed in human prostate cancer in vivo and is involved in the in vitro invasion of PC3 and LNCap cells. Cancer Science 99 1362-1369.

Huang J, Yao JL, Zhang L, Bourne PA, Quinn AM, di Sant'Agnese PA \& Reeder JE 2005 Differential expression of interleukin- 8 and its receptors in the neuroendocrine and non-neuroendocrine compartments of prostate cancer. American Journal of Pathology 166 1807-1815. 
Inoue K, Slaton JW, Eve BY, Kim SJ, Perrotte P, Balbay MD, Yano S, Bar-Eli M, Radinsky R, Pettaway CA et al. 2000 Interleukin 8 expression regulates tumorigenicity and metastases in androgen-independent prostate cancer. Clinical Cancer Research 6 2104-2119.

Jamieson WL, Shimizu S, D’ Ambrosio JA, Meucci O \& Fatatis A 2008 CX3CR1 is expressed by prostate epithelial cells and androgens regulate the levels of CX3CL1/fractalkine in the bone marrow: potential role in prostate cancer bone tropism. Cancer Research $\mathbf{6 8}$ 1715-1722.

Javidan J, Deitch AD, Shi XB \& de Vere White RW 2005 The androgen receptor and mechanisms for androgen independence in prostate cancer. Cancer Investigation $\mathbf{2 3}$ 520-528.

Jemal A, Siegel R, Ward E, Murray T, Xu J, Smigal C \& Thun MJ 2006 Cancer statistics, 2006. CA: A Cancer Journal for Clinicians 56 106-130.

Kim SJ, Uehara H, Karashima T, McCarty M, Shih N \& Fidler IJ 2001 Expression of interleukin-8 correlates with angiogenesis, tumorigenicity, and metastasis of human prostate cancer cells implanted orthotopically in nude mice. Neoplasia 3 33-42.

Kukreja P, Abdel-Mageed AB, Mondal D, Liu K \& Agrawal KC 2005 Up-regulation of CXCR4 expression in PC-3 cells by stromal-derived factor-1 $\alpha$ (CXCL12) increases endothelial adhesion and transendothelial migration: role of MEK/ERK signaling pathwaydependent NF- $\kappa \mathrm{B}$ activation. Cancer Research $\mathbf{6 5}$ 9891-9898.

Lazennec G \& Jorgensen C 2008 Concise review: adult multipotent stromal cells and cancer: risk or benefit? Stem Cells 26 1387-1394.

Lee LF, Louie MC, Desai SJ, Yang J, Chen HW, Evans CP \& Kung HJ 2004 Interleukin-8 confers androgen-independent growth and migration of LNCaP: differential effects of tyrosine kinases Src and FAK. Oncogene $\mathbf{2 3}$ 2197-2205.

Lehrer S, Diamond EJ, Mamkine B, Stone NN \& Stock RG 2004 Serum interleukin-8 is elevated in men with prostate cancer and bone metastases. Technology in Cancer Research \& Treatment 3411.

Loberg RD, Day LL, Harwood J, Ying C, St John LN, Giles R, Neeley CK \& Pienta KJ 2006 CCL2 is a potent regulator of prostate cancer cell migration and proliferation. Neoplasia 8 578-586.

Loberg RD, Ying C, Craig M, Yan L, Snyder LA \& Pienta KJ 2007 CCL2 as an important mediator of prostate cancer growth in vivo through the regulation of macrophage infiltration. Neoplasia 9 556-562.

Logothetis CJ \& Lin SH 2005 Osteoblasts in prostate cancer metastasis to bone. Nature Reviews. Cancer 5 21-28.

Lu Y, Cai Z, Galson DL, Xiao G, Liu Y, George DE, Melhem MF, Yao Z \& Zhang J 2006 Monocyte chemotactic protein-1 (MCP-1) acts as a paracrine and autocrine factor for prostate cancer growth and invasion. Prostate 66 1311-1318.
Lu Y, Cai Z, Xiao G, Keller ET, Mizokami A, Yao Z, Roodman GD \& Zhang J 2007a Monocyte chemotactic protein-1 mediates prostate cancer-induced bone resorption. Cancer Research 67 3646-3653.

Lu Y, Cai Z, Xiao G, Liu Y, Keller ET, Yao Z \& Zhang J $2007 b$ CCR2 expression correlates with prostate cancer progression. Journal of Cellular Biochemistry 101 676-685.

Mazzucchelli L, Loetscher P, Kappeler A, Uguccioni M, Baggiolini M, Laissue JA \& Mueller C 1996 Monocyte chemoattractant protein-1 gene expression in prostatic hyperplasia and prostate adenocarcinoma. American Journal of Pathology 149 501-509.

Moore BB, Arenberg DA, Stoy K, Morgan T, Addison CL, Morris SB, Glass M, Wilke C, Xue YY, Sitterding S et al. 1999 Distinct CXC chemokines mediate tumorigenicity of prostate cancer cells. American Journal of Pathology 154 1503-1512.

Murphy C, McGurk M, Pettigrew J, Santinelli A, Mazzucchelli R, Johnston PG, Montironi R \& Waugh DJ 2005 Nonapical and cytoplasmic expression of interleukin-8, CXCR1, and CXCR2 correlates with cell proliferation and microvessel density in prostate cancer. Clinical Cancer Research 11 4117-4127.

Nagpal ML, Davis J \& Lin T 2006 Overexpression of CXCL10 in human prostate LNCaP cells activates its receptor (CXCR3) expression and inhibits cell proliferation. Biochimica et Biophysica Acta 1762 811-818.

Nibbs RJ, Wylie SM, Pragnell IB \& Graham GJ 1997 Cloning and characterization of a novel murine beta chemokine receptor, D6. Comparison to three other related macrophage inflammatory protein-1 $\alpha$ receptors, CCR-1, CCR-3, and CCR-5. Journal of Biological Chemistry 272 12495-12504.

Olumi AF, Grossfeld GD, Hayward SW, Carroll PR, Tlsty TD \& Cunha GR 1999 Carcinoma-associated fibroblasts direct tumor progression of initiated human prostatic epithelium. Cancer Research 59 5002-5011.

Peiper SC, Wang ZX, Neote K, Martin AW, Showell HJ, Conklyn MJ, Ogborne K, Hadley TJ, Lu ZH, Hesselgesser J et al. 1995 The Duffy antigen/receptor for chemokines (DARC) is expressed in endothelial cells of Duffy negative individuals who lack the erythrocyte receptor. Journal of Experimental Medicine 181 1311-1317.

Penna G, Fibbi B, Amuchastegui S, Corsiero E, Laverny G, Silvestrini E, Chavalmane A, Morelli A, Sarchielli E, Vannelli GB et al. 2008 The vitamin D receptor agonist elocalcitol inhibits IL-8-dependent benign prostatic hyperplasia stromal cell proliferation and inflammatory response by targeting the RhoA/Rho kinase and NF-kB pathways. Prostate 69 480-493.

Proudfoot AE, Handel TM, Johnson Z, Lau EK, LiWang P, Clark-Lewis I, Borlat F, Wells TN \& Kosco-Vilbois MH 2003 Glycosaminoglycan binding and oligomerization are essential for the in vivo activity of certain chemokines. PNAS 100 1885-1890. 
Rajarathnam K, Sykes BD, Kay CM, Dewald B, Geiser T, Baggiolini M \& Clark-Lewis I 1994 Neutrophil activation by monomeric interleukin-8. Science 264 90-92.

Reiland J, Furcht LT \& McCarthy JB 1999 CXCchemokines, stimulate invasion and chemotaxis in prostate carcinoma cells through the CXCR2 receptor. Prostate 41 78-88.

Richmond A 2002 NF- $\kappa$ B, chemokine gene transcription and tumour growth. Nature Reviews. Immunology 2 664-674.

Rossi D \& Zlotnik A 2000 The biology of chemokines and their receptors. Annual Review of Immunology 18 217-242.

Schauer IG, Ressler SJ \& Rowley DR 2008a Keratinocytederived chemokine induces prostate epithelial hyperplasia and reactive stroma in a novel transgenic mouse model. Prostate 69 373-384.

Schauer IG, Ressler SJ, Tuxhorn JA, Dang TD \& Rowley DR $2008 b$ Elevated epithelial expression of interleukin-8 correlates with myofibroblast reactive stroma in benign prostatic hyperplasia. Urology 72 205-213.

Schwarze SR, Luo J, Isaacs WB \& Jarrard DF 2005 Modulation of CXCL14 (BRAK) expression in prostate cancer. Prostate 64 67-74.

Seaton A, Scullin P, Maxwell PJ, Wilson C, Pettigrew J, Gallagher R, O'Sullivan JM, Johnston PG \& Waugh DJ 2008 Interleukin-8 signaling promotes androgen-independent proliferation of prostate cancer cells via induction of androgen receptor expression and activation.

Carcinogenesis 29 1148-1156.

Shen H, Schuster R, Lu B, Waltz SE \& Lentsch AB $2006 a$ Critical and opposing roles of the chemokine receptors CXCR2 and CXCR3 in prostate tumor growth. Prostate 66 1721-1728.

Shen H, Schuster R, Stringer KF, Waltz SE \& Lentsch AB $2006 b$ The Duffy antigen/receptor for chemokines (DARC) regulates prostate tumor growth. FASEB Journal 20 59-64.

Shulby SA, Dolloff NG, Stearns ME, Meucci O \& Fatatis A 2004 CX3CR1-fractalkine expression regulates cellular mechanisms involved in adhesion, migration, and survival of human prostate cancer cells. Cancer Research 64 4693-4698.

Sun YX, Schneider A, Jung Y, Wang J, Dai J, Wang J, Cook K, Osman NI, Koh-Paige AJ, Shim H et al. 2005 Skeletal localization and neutralization of the SDF-1(CXCL12)/CXCR4 axis blocks prostate cancer metastasis and growth in osseous sites in vivo. Journal of Bone and Mineral Research 20 318-329.

Szabo MC, Soo KS, Zlotnik A \& Schall TJ 1995 Chemokine class differences in binding to the Duffy antigenerythrocyte chemokine receptor. Journal of Biological Chemistry $27025348-25351$.

Taichman RS, Cooper C, Keller ET, Pienta KJ, Taichman NS \& McCauley LK 2002 Use of the stromal cell-derived factor-1/CXCR4 pathway in prostate cancer metastasis to bone. Cancer Research 62 1832-1837.
Taplin ME 2007 Drug insight: role of the androgen receptor in the development and progression of prostate cancer. Nature Clinical Practice. Oncology 4 236-244.

Thelen M 2001 Dancing to the tune of chemokines. Nature Immunology 2 129-134.

Uehara H, Troncoso P, Johnston D, Bucana CD, Dinney C, Dong Z, Fidler IJ \& Pettaway CA 2005 Expression of interleukin- 8 gene in radical prostatectomy specimens is associated with advanced pathologic stage. Prostate 64 40-49.

Vaday GG, Peehl DM, Kadam PA \& Lawrence DM 2006 Expression of CCL5 (RANTES) and CCR5 in prostate cancer. Prostate 66 124-134.

Veltri RW, Miller MC, Zhao G, Ng A, Marley GM, Wright GL Jr, Vessella RL \& Ralph D 1999 Interleukin-8 serum levels in patients with benign prostatic hyperplasia and prostate cancer. Urology 53 139-147.

Wallace TA, Prueitt RL, Yi M, Howe TM, Gillespie JW, Yfantis HG, Stephens RM, Caporaso NE, Loffredo CA \& Ambs S 2008 Tumor immunobiological differences in prostate cancer between African-American and European-American men. Cancer Research 68 927-936.

Wang J, Wang J, Sun Y, Song W, Nor JE, Wang CY \& Taichman RS 2005 Diverse signaling pathways through the SDF-1/CXCR4 chemokine axis in prostate cancer cell lines leads to altered patterns of cytokine secretion and angiogenesis. Cellular Signalling 17 1578-1592.

Wang J, Wang J, Dai J, Jung Y, Wei CL, Wang Y, Havens AM, Hogg PJ, Keller ET, Pienta KJ et al. 2007 A glycolytic mechanism regulating an angiogenic switch in prostate cancer. Cancer Research 67 149-159.

Wang J, Shiozawa Y, Wang J, Wang Y, Jung Y, Pienta KJ, Mehra R, Loberg R \& Taichman RS 2008 The role of CXCR7/RDC1 as a chemokine receptor for CXCL12/SDF-1 in prostate cancer. Journal of Biological Chemistry 283 4283-4294.

Xu Y, Josson S, Fang F, Oberley TD, St Clair DK, Wan XS, Sun Y, Bakthavatchalu V, Muthuswamy A \& St Clair WH 2009 RelB enhances prostate cancer growth: implications for the role of the nuclear factor $-\kappa \mathrm{B}$ alternative pathway in tumorigenicity. Cancer Research 69 3267-3271.

Yang HP, Woodson K, Taylor PR, Pietinen P, Albanes D, Virtamo J \& Tangrea JA 2006 Genetic variation in interleukin 8 and its receptor genes and its influence on the risk and prognosis of prostate cancer among Finnish men in a large cancer prevention trial. European Journal of Cancer Prevention 15 249-253.

Zhang S, Qi L, Li M, Zhang D, Xu S, Wang N \& Sun B 2008 Chemokine CXCL12 and its receptor CXCR4 expression are associated with perineural invasion of prostate cancer. Journal of Experimental and Clinical Cancer Research 2762. 